\title{
What and How is BIPA Teaching through Online Media?
}

\author{
Nani Darmayanti ${ }^{1}$ and Mayasari $^{2}$ \\ ${ }^{1}$ Universitas Padjadjaran, Indonesia, \\ ${ }^{2}$ Universitas Singaperbangsa Karawang, Indonesia \\ $\underline{{ }^{1} \text {.darmayanti@unpad.ac.id }{ }^{2} \text { mayasari@fisip.unsika.ac.id }}$
}

\begin{abstract}
This study examines any online media that organizes Indonesian language teaching for foreign speakers. The research method used is a qualitative descriptive method. The results showed that teaching Bahasa for foreign speakers is very diverse. All Indonesian learning rides are paid, and some are not paid. As for the material aspect, there is a service provider that has made the rating as did the Indonesian Agency of the Republic of Indonesia, namely A1-C2 and there are also those who provide the material based on a particular thematic. These service providers are created by writers from various countries, from Indonesian writers themselves to American and European writers. The background of those who utilize this media of learning as diverse as going to travel to Indonesia, having a business in Indonesia, married to Indonesians, interested in Indonesian culture, or want to invest in Indonesia. The presence of online media in this BIPA lesson service is very beneficial for those who want to learn Indonesian from their own country.
\end{abstract}

Keywords: BIPA, Language, Teaching, Online Media

\section{PENDAHULUAN}

BIPA adalah program pembelajaran keterampilan berbahasa Indonesia (membaca, menulis, mendengarkan, dan berbicara) bagi penutur asing. Adapun tujuan program BIPA adalah meningkatkan citra positif Indonesia di dunia internasional dalam rangka menjadikan bahasa Indonesia sebagai bahasa perhubungan luas pada tingkat antarbangsa [1].

Pengajaran Bahasa Indonesia bagi Penutur Asing (BIPA) selain diselenggarakan oleh institusi/lembaga resmi, juga diselenggarakan oleh berbagai pihak melalui media dalam jaringan (daring/online) [2]. Banyaknya lembaga pengajaran BIPA baik di dalam, maupun di luar negeri merupakan bentuk respon positif atas minat orang asing belajar BIPA [3] dan [4].

Setakat ini pengajaran BIPA melalui media daring semakin berkembang. Hal ini dilatarbelakangi oleh perkembangan teknologi internet yang sangat pesat hingga merambah ke berbagai aspek kehidupan manusia, termasuk pendidikan dan pembelajaran [5]. Selain itu pengajaran BIPA daring juga dipengaruhi oleh faktor generasi penggunanya.

Pelajar BIPA pada umumnya adalah orang dewasa yang berusia 17 tahun ke atas [6]. Dengan kata lain, kegiatan pembelajaran BIPA banyak diikuti oleh generasi $\mathrm{Z}$ atau digital age [7]. Generasi ini disebut juga sebagai kaum penduduk asli dunia digital (digital native) dengan indikator kelahiran di atas tahun 1980 dan mereka memiliki karakteristik terbiasa mengolah informasi secara digital dengan beragam perangkat teknologi informasi. 
Selain itu, maraknya pembelajaran melalui media daring juga karena pembelajaran Bahasa Indonesia bagi Penutur Asing (BIPA) yang bersifat teoretis berbentuk teks-teks kurang efektif karena tidak menstimulus kemampuan pembelajar [8]. Motivasi pembelajar juga menjadi masalah terbesar pada pembelajaran BIPA konvensional. Ada banyak alasan peserta kurang termotivasi dalam belajar BIPA, salah satunya ialah suasana kelas yang membosankan [9].

Penggunaan media sosial dalam pembelajaran adalah hal lumrah saat ini. Media ini dapat digunakan selain sebagai media langsung dalam pembelajaran juga dapat digunakan untuk membantu pengelolaan pembelajaran [10] .Penggunaan media daring sebagai sarana belajar BIPA memudahkan siapa pun, di mana pun, dan kapan pun untuk belajar bahasa Indonesia tanpa harus tinggal di Indonesia seperti yang harus dilakukan jika siswa belajar di kelas BIPA secara konvensional.

Hal ini juga seiring dengan semangat revolusi industri 4.0, yaitu teknologi informasi telah menjadi basis dalam kehidupan manusia. Segala hal menjadi tanpa batas karena dipengaruhi oleh perkembangan internet dan teknologi digital yang masif sebagai tulang punggung pergerakan dan konektivitas manusia dan mesin [11].

Uraian singkat di atas menunjukkan bahwa pembelajaran BIPA melalui media daring juga tidak kalah menarik dari pembelajaran BIPA di kelas konvensional. Oleh karena itu, penelitian ini akan mengkaji pengajaran BIPA yang diselenggarakan melalui media daring dan dikaji berdasarkan negara penyelenggaranya, biayanya, materinya, dan motivasi pesertanya.

Penelitian ini penting sebagai bentuk pemetaan pengajaran BIPA, khusunya pengajaran melalui media daring. Dengan demikian, penelitian ini dapat menjadi informasi berharga bagi pihak terkait yang bermaksud membuat layanan pengajaran BIPA melalui media daring. Selain itu penelitian ini juga bermanfaat bagi pihak-pihak atau siswa yang bermaksud mengikuti pembelajaran BIPA secara daring. Mereka menjadi tahu media daring mana yang dapat dipilih untuk proses pembelajaran mereka.

\section{METODE PENELITIAN}

Metode yang digunakan dalam penelitian ini adalah metode kualitatif dengan penyajian data bersifat deskriptif.[12] Pengumpulan data dilakukan dengan teknik literatur. Dalam hal ini peneliti melakukan penelusuran melalui mesin pencari, media daring mana saja yang memberikan layanan pengajaran bahasa Indonesia bagi penutur asing. Pencarian difokuskan pada pengajaran BIPA yang terdapat pada youtube, instagram, facebook, situs web, dan aplikasi google di telepon genggam. Peneliti memilih penyelenggara BIPA yang berada di urutan teratas di seluruh media daring tersebut di atas. Setelah itu, peneliti mengklasifikasi dan menganalisis data tersebut berdasarkan asal negara penyelenggaranya, biayanya, materinya, serta motivasi pesertanya.

\section{HASIL DAN PEMBAHASAN}

Hasil penelitian berdasarkan teknik penelitian yang dilakukan oleh peneliti menunjukkan bahwa ada 18 penyelanggara pengajaran BIPA secara daring yang terdapat pada media youtube, instagram, facebook, situs web, dan aplikasi google. 
Tabel 1 Penyelenggara Pengajaran BIPA Daring (online)

\begin{tabular}{|c|c|c|c|c|c|}
\hline No & $\begin{array}{l}\text { Media Dalam Jaringan } \\
\text { (Daring/Online) }\end{array}$ & $\begin{array}{c}\text { Asal } \\
\text { Negara }\end{array}$ & $\begin{array}{l}\text { Jenis } \\
\text { Daring }\end{array}$ & $\begin{array}{c}\text { Biaya } \\
\text { (Tuition fee) }\end{array}$ & Materi \\
\hline 1 & https://indonesian-Online.com & USA & situs web & berbayar & A1-C2 \\
\hline 2 & https://www.learnindonesian.education & Indonesia & situs web & berbayar & $\mathrm{A} 1-\mathrm{C} 2$ \\
\hline 3 & http://kelasbahasa.com & Indonesia & situs web & berbayar & Tematik \\
\hline 4 & https://www.babbel.com & Eropa & situs web & berbayar & Tematik \\
\hline 5 & https://id.duolingo.com & Indonesia & situs web & $\begin{array}{l}\text { tidak } \\
\text { berbayar }\end{array}$ & Tematik \\
\hline 6 & $\begin{array}{l}\text { https://www.learningindonesian.com/fr } \\
\text { ee }\end{array}$ & USA & situs web & $\begin{array}{l}\text { tidak } \\
\text { berbayar }\end{array}$ & Tematik \\
\hline 7 & $\begin{array}{l}\text { https://www.loecsen.com/en/learn- } \\
\text { indonesian }\end{array}$ & Perancis & situs web & $\begin{array}{l}\text { tidak } \\
\text { berbayar }\end{array}$ & Tematik \\
\hline 8 & https://japanesia.net/1047.html & Jepang & situs web & $\begin{array}{l}\text { tidak } \\
\text { berbayar }\end{array}$ & Tematik \\
\hline 9 & @belajarbahasaIndonesia & Indonesia & Facebook & $\begin{array}{l}\text { tidak } \\
\text { berbayar }\end{array}$ & Tematik \\
\hline 10 & @griyabahasa & Indonesia & Facebook & $\begin{array}{l}\text { tidak } \\
\text { berbayar }\end{array}$ & Tematik \\
\hline 11 & $\begin{array}{l}\text { https://www.youtube.com/watch?v=w } \\
\text { aAzM9WsY QY }\end{array}$ & Indonesia & Youtube & $\begin{array}{l}\text { tidak } \\
\text { berbayar }\end{array}$ & Tematik \\
\hline 12 & $\begin{array}{l}\text { https://www.youtube.com/watch?v= } \\
\text { BcfZLSzMeP s }\end{array}$ & Jepang & Youtube & $\begin{array}{l}\text { tidak } \\
\text { berbayar }\end{array}$ & Tematik \\
\hline 13 & $\begin{array}{l}\text { https://www.youtube.com/watch?v=m- } \\
\text { IH3st1poE }\end{array}$ & Perancis & Youtube & $\begin{array}{l}\text { tidak } \\
\text { berbayar }\end{array}$ & Tematik \\
\hline 14 & @learnindonesianword & Indonesia & Instagram & $\begin{array}{l}\text { tidak } \\
\text { berbayar }\end{array}$ & Tematik \\
\hline 15 & @endonezceye dair & Turki & Instagram & $\begin{array}{l}\text { tidak } \\
\text { berbayar }\end{array}$ & Tematik \\
\hline 16 & http://www.rasabahasa.edu.au/ & Australia & aplikasi HP & $\begin{array}{l}\text { tidak } \\
\text { berbayar }\end{array}$ & Tematik \\
\hline 17 & $\begin{array}{l}\text { https://itunes.apple.com/us/app/in- } \\
\text { 24-hours-learn- indonesian }\end{array}$ & Australia & aplikasi HP & $\begin{array}{l}\text { tidak } \\
\text { berbayar }\end{array}$ & Tematik \\
\hline 18 & $\begin{array}{l}\text { https://itunes.apple.com/id/app/baha } \\
\text { sa-indonesia- nemo }\end{array}$ & USA & aplikasi HP & $\begin{array}{l}\text { tidak } \\
\text { berbayar }\end{array}$ & Tematik \\
\hline
\end{tabular}

\subsection{BIPA Daring Berdasarkan Asal Negara}

Hasil analisis menunjukkan bahwa asal negara yang menyelenggarakan pengajaran bahasa Indonesia bagi Penutur Asing secara daring adalah sangat beragam. Ada dari Indonesia, Amerika Serikat (USA), Perancis, Jepang, Turki, Perancis, dan Australia. Meski berasal dari negara yang berbeda-beda, namun seluruh aplikasi BIPA yang mereka ciptakan dapat diakses oleh seluruh pihak di seluruh belahan dunia. 


\subsection{BIPA Daring Berdasarkan Medianya}

Berdasarkan jenisnya media daringnya, pengajaran bahasa Indonesia bagi Penutur Asing (BIPA) yang diselenggarakan secara daring cukup beragam. Hasil penelusuran berdasarkan mesin pencari menunjukkan bahwa terdapat tujuh media dalam bentuk situs web, dua media dalam bentuk media sosial facebook, tiga media dalam bentuk youtube, dan tiga media melalui aplikasi telepon genggam (HP). Sebenarnya media daring yang menyelenggarakan pelajaran bahasa Indonesia ini sangat banyak bahkan berjumlah ratusan, namun peneliti hanya memilih delapan belas media daring yang paling aktif dan diminati oleh warga net (netizen). Media sosial facebook@belajarbahasaindonesia misalnya, diikuti oleh oleh lebih dari 1.200 orang dari berbagai negara.

\subsection{BIPA Daring Berdasarkan Biayanya}

Sebagian besar media daring penyelenggara BIPA tidak menetapkan bayaran dalam layanan yang diberikan. Meskipun demikian ada juga media daring yang menetapkan bahwa layanan mereka adalah layanan berbayar. Misanya pada media dari berjenis situs web https://indonesian-Online.com. Pihaknya menetapkan biaya berlangganan dalam tiga jenis, yatu Silver, Gold, dan Patinum. Silver USD 60 per tahun, Gold USD 100 per dua tahun, Platinum USD 150 tanpa batas waktu. Situs web https://kelasbahasa.com asal Indonesia menetapkan tarif Rp375.000,00 / bulan untuk 4 sesi chatting (@ 1jam), dan 4 sesi berbicara (30 menit). Sementara itu, situs web dari Indonesia https://www.learnindonesian.education menetapkan harga kursus selama 156 jam berdasarkan jumlah peserta kursus dalam jaringan yang dapat diakses dari belahan dunia mana pun. Situs ini menetapkan harga Rp6.500.000,00 jika peserta kursus daring berjumlah 1 orang, Rp9.750.000,00 jika peserta kursus daring berjumlah 2 orang, Rp12.185.000,00 jika peserta kursus berjumlah 3 orang, dan Rp13.000.000,00 jika jumlah peserta kursus adalah 4 orang.

\subsection{BIPA Daring Berdasarkan Penjenjangan Materinya}

Berdasarkan materi yang diajarkannya, media daring terbagi menjadi dua, yaitu ada media daring yang sudah melakukan penjenjangan materi sesuai dengan yang dilakukan Badan Bahasa yang mengacu pada sistem CEFR dan sebagian besar media lainnya menyajikan materi berdasarkan tematik dan konteks. Media daring yang melakukan penjenjangan A1-C2 adalah hanya situs web https://indonesia-Online.com dan https://www.learningindonesia.education. Sementara itu, pada media daring yang isi materinya berlandaskan pada tema, umumnya berisi materi yang diklasifikasikan ke dalam tema salam, di sekolah, di rumah, di kampus, di pasar, di kampus, dan materi kosakata yang dilengkapi dengan audio dan visual sehingga memudahkan pembelajar dalam memahami materi.

\subsection{BIPA Daring Berdasarkan Motivasi Peserta}

Hasil pengamatan pada sebagian identitas pengguna layanan BIPA daring ini menunjukkan bahwa latar belakang keikutsertaan atau motivasi dalam pelajaran BIPA daring ini, di antaranya adalah (1) adanya hubungan bisnis yang dilakukan oleh para pelaku bisnis di negara lain dengan pelaku bisnis di Indonesia sehingga mereka merasa perlu memiliki kemampuan dasar dalam berbahasa Indonesia. (2) ada yang akan berlibur ke Indonesia sehingga membutuhkan pengetahuan dasar bahasa Indonesia seperti materi salam, berbelanja, memesan 
hotel, dan memesan taksi. (3) ada pula yang akan atau sudah menikan dengan orang Indonesia sehingga untuk memperlancar komunikasi dengan pasangannya, mereka mempelajari bahasa Indonesia. (4) ada yang bertujuan studi di Indonesia sehingga perlu pengetahuan dasar bahasa Indonesia. (5) ada yang akan bekerja di Indonesia sehingga pemahaman budaya Indonesia diawali dengan mempelajari bahasa Indonesia [13].

\section{PENUTUP}

Hasil penelitian menunjukkan bahwa media yang menyediakan pengajaran Bahasa Indonesia bagi Penutur Asing sangat beragam, mulai dari berbentuk situs web, Facebook, Instagram, hingga aplikasi pada telepon genggam. Seluruh wahana pembelajaran bahasa Indonesia itu ada yang berbayar, dan ada juga yang tidak berbayar. Adapun dari aspek materi, ada penyedia layanan yang sudah melakukan pemeringkatan seperti yang telah dilakukan Badan Bahasa Republik Indonesia, yaitu A1-C2 dan ada juga yang yang menyediakan materinya berdasarkan tematik tertentu. Penyedia layanan ini dibuat oleh para penulis dari berbagai negara, mulai dari penulis Indonesia sendiri hingga penulis dari Amerika dan Eropa. Latar belakang mereka yang memanfaatkan media pembelajaran ini bermacam-macam seperti akan berwisata ke Indonesia, memiliki bisnis di Indonesia, menikah dengan orang Indonesia, tertarik dengan budaya Indonesia, atau ingin berinvestasi di Indonesia. Kehadiran media daring layanan pelajaran BIPA ini sangat bermanfaat bagi mereka yang ingin belajar bahasa Indonesia dari negara mereka masing-masing.

\section{REFERENCES}

[1] D. Untari, "Pembelajaran Bipa Melalui Analisis Semantik Pada Meme- Meme Berbahasa Indonesia Dalam Media Sosial (Pembelajaran Berbasis Media)," in Simposium Internasional Pengajaran BIPA, 2017, p. 149.

[2] A. Kusmiatun, "Tantangan dan strategi pemelajaran bipa bermuatan nilai karakter profetik," in Pertemuan Ilmiah Bahasa dan Satra (PIBSI) XL 2018, 2018, vol. 781, no. 1, pp. 781-788.

[3] N. Pt et al., "Pembelajaran Bahasa Indonesia Bagi Penutur Asing," J. Prodi Bhs. dan Sastra Indones. Undiksha, vol. 3, no. 5, 2016.

[4] P. J. Hun, "Potensi dan Tantangan Bahasa Indonesia Menuju Bahasa InternasionaL," Sosioteknologi, vol. 14, no. 12-20, 2015.

[5] N. Darmayanti, "Pengajaran Bahasa Indonesia di China : Peluang dan Tantangan," in Bahasa, Sastra dan Budaya dalam Pengajaran BIPA, Unpad 2018.

[6] I. Suyitno, "Pengembangan Bahan Ajar Bahasa Indonesia untuk Penutur Asing (BIPA) berdasarkan Hasil Analisis Kebutuhan Belajar," Wacana, J. Humanit. Indones., vol. 9, no. 1, p. 62, 2007.

[7] D. Widyartono, "Pembelajaran Bahasa Indonesia untuk Penutur Asing Berbasis Blended Learning," in Konferensi Internasional Pengajaran BIPA: Pemartabatan Bahasa Indonesia dalam Menghadapi Perubahan Konstelasi Politik dan Ekonomi Dunia, 2017, no. October, pp. 3-8.

[8] M. Zaenuri and T. Yuniawan, "Pengembangan Laman Media Audiovisual Bermuatan Materi Kebudayaan Indonesia Sebagai Media Pembelajaran BIPA," Deiksis - J. Pendidik. Bhs. dan sastra Indones., vol. 7, no. 1, pp. 35-43, 1994.

[9] R. Ramliyana, "Penerapan Media Komik Pada Pembelajaran Bipa ( Studi Kasus pada Peserta Korea Tingkat Pemula di Universitas Trisakti Jakarta ), ’ J. SAP, vol. 1, no. 1, pp. 8-17, 2016.

[10] H. Widiyanto, "Pembelajaran Bahasa Indonesia Bagi Penutur Asing: Peneguh 
Persatuan Atas Kebinekaan Indonesia,” in PS PBSI Universitas Jember, 2018, pp. 125 134.

[11] Ristekdikti, "Pengembangan Iptek dan Pendidikan Tinggi di Era Revolusi Industri 4.0," 17 Januari, 2018.

[12] M. B. Miles and M. A. Huberman, Analisis Data Kualitatif: Buku Sumber Tentang Metode-Metode Baru. 2012.

[13] K. Saddhono, A. Hasibuan, and M. I. Bakhtiar, "Facebook as A Learning Media in TISOL (Teaching Indonesian to Speakers of Other Languages) Learning to Support The Independency of Foreign Students in Indonesia," in Journal of Physics: Conference Series, 2019, vol. 1254, no. 1, p. 12061. 